\title{
Factors Related to Practice of Patient Safety among Nurses in Ratu Zalecha Hospital Martapura
}

\author{
Rokayah $^{1}$, Musafaah $^{2}$, Ratna Setyaningrum ${ }^{3}$ \\ \{rokayahjuna03@gmail.com¹, musafaah81@gmail.com², ratnasetyaningrum@ulm.ac.id ${ }^{3}$ \} \\ Medical Faculty, Lambung Mangkurat University, Banjarbaru, Indonesia ${ }^{1-3}$
}

\begin{abstract}
Ratu Zalecha Hospital Martapura is one of the referral hospitals in the Province of South Kalimantan. Data from Hospital Occupational Health and Safety (OHS) Department shows several occurrences of Healthcare-Associated Infections (HAIs) in the practice of patient safety. Human behavior still one of the highest factors in work accidents. This study aims to analyze the relationship between knowledge, training, and compliance with Personal Protective Equipment (PPE) with the practice of patient safety in Ratu Zalecha Hospital. This research uses a quantitative method with analytic observational design through the cross-sectional approach. The population of this study was all nurses in Ratu Zalecha Martapura Hospital. The calculation of the sample used two different test formulas with the proportion of 42 people taken with a proportional random sampling technique and using the chi-square test with $95 \%$ confidence level. The results show that there is a correlation between knowledge, training, and PPE compliance with the practice of patient safety p-value 0.026 for knowledge, 0.003 for training, and 0.015 for PPE compliance. Therefore it is recommended that hospitals can increase nurses' knowledge with OHS promotion, improve training provision, and improve PPE compliance with rewards.
\end{abstract}

Keywords: knowledge, PPE compliance, the practice of patient safety, training

\section{Introduction}

One of the public health problems that affect the level of country development is patient safety. In 2011, the World Health Organization (WHO) mentioned 23 cities in America had experienced medication errors and unsafe injections without sterile devices contributing $40 \%$ worldwide, causing infections in hospital patients. Estimated 1.3 million deaths each year are caused by the unsafe injection. Hospital accreditation committee has set patient safety goals as one of the accreditation standards adopted from the Joint Commission International (JCI) in 2011 to become one of the 2012 accreditation standards required by hospitals [1].

Based on data from the Health Ministry of the Republic of Indonesia in 2011, the incidence of violations of patient safety $28.3 \%$ was carried out by nurses [2]. Though nurses should have realized its role as a health service provider must be able to participate in realizing patient safety actively. Nurse hard work cannot reach the optimal point if it is not supported by infrastructure, hospital management, and other health workers [3].

According to Mitchell in Hughes (2008), nurses are the key to the development of service quality through patient safety. Data of HAIs incidences in 2017 in Ratu Zalecha Hospital Martapura, namely $9.77 \%$ phlebitis, $2 \%$ for operation area infections, $1.15 \%$ for urinary tract 
infections (UTI). Ratu Zalecha Regional General Hospital (RSUD) is one hospital type B Education and became the second referral center after RSUD Ulin Banjarmasin in South Kalimantan. It covers the regional city of Banjarbaru, Banjar District, Tapin District, and Tanah Laut District [4].

Based on the results of the study conducted by Manorek, et al. (2017) showed the training of nurses on patient safety related to the implementation of patient safety in the inpatient unit general hospital Dr. Sam Ratulangi Tondan. Based on the study by Arfianto (2017) that nurses' adherence to the use of PPE affects the application of patient safety to reduce the risk of infection in patients who receive health services at Roemani Muhammadiyah Hospital Semarang. Nurses' attitudes toward patient safety are also related to patient safety behaviors in the study of Sualang, et al. (2014). Based on this description, it is important to analyze factors related to the practice of patient safety among nurses in Ratu Zalecha Hospital Martapura [5]-[7].

\section{Method}

This is quantitative research with the cross-sectional approach and uses sampling technique with purposive sampling as many as 42 respondents. Sample selection with inclusion criteria as follows: a. Nurses in the inpatient nerve, surgery, and perinatology room where at units have a greater risk of occurrence of KTD than other units; $b$. Not on leave. Instruments used in this research are observation sheets and questionnaires. The questionnaire consists of independent variables with an assessment that is, the knowledge variable and the maximum compliance with minimum values divided into two is obtained on average question results, attitude and perception variables for positive and negative questions the maximum value-minimum value is divided into two the average results are obtained questions, and the skill variable for the minimum-value maximum questions the value is divided into 2 , the average result of the question is obtained. Then for observation sheets are used for bound variables with maximum-minimum values, the value is divided into 2 . The average result of the question is obtained. Bivariate analysis using chi-square statistical tests with a significance level of $95 \%$.

\section{Result}

\subsection{Univariate Analysis}

The practice of patient safety in this research is defined as an act or action by respondents who do a job or activity regarding the value for patient safety. From the primary data results of 42 respondents who exist in space ambulatory inpatient surgery, hospitalization nerves, and ICU obtained as follows.

Table 1. shows an overview of the blood sugar levels of respondents based on gender, age, education level, duration of suffering from diabetes, and family support. Most of the respondents were women, and $51.6 \%$ of them had uncontrolled blood glucose levels. Uncontrolled blood sugar was dominated by respondents with age $<64$ years $(57.9 \%)$, a higher education level (graduating college) (80\%), suffering from DM more than five years (71\%), and not receiving family support for treatment $(62.5 \%)$. 
Table 1. Distribution of Respondent Frequencies Based on the Practice of Patient Safety, Knowledge, Training, and Compliance of PPE in Ratu Zalecha Hospital Martapura

\begin{tabular}{|c|c|c|c|c|c|c|}
\hline \multirow{3}{*}{ Variable } & \multicolumn{6}{|c|}{ The practice of Patient Safety } \\
\hline & \multicolumn{2}{|c|}{ Less } & \multicolumn{2}{|c|}{ Good } & \multicolumn{2}{|c|}{ Total } \\
\hline & $\mathbf{n}$ & $\%$ & $\mathrm{n}$ & $\%$ & $\mathbf{n}$ & $\%$ \\
\hline \multicolumn{7}{|l|}{ Knowledge } \\
\hline Less & 7 & 58.3 & 5 & 41.7 & 12 & 100,0 \\
\hline Good & 6 & 20.0 & 24 & 80.0 & 30 & 100,0 \\
\hline \multicolumn{7}{|l|}{ Training } \\
\hline Never & 9 & 64.3 & 5 & 35.7 & 14 & 100,0 \\
\hline Experienced & 4 & 14.3 & 24 & 85.7 & 28 & 100,0 \\
\hline \multicolumn{7}{|l|}{ PPE Compliance } \\
\hline Less & 10 & 52.6 & 9 & 47.4 & 19 & 100,0 \\
\hline Good & 3 & 13.0 & 20 & 87.0 & 23 & 100,0 \\
\hline
\end{tabular}

Based on the analysis of the correlation between knowledge, training, and PPE compliance with the practice of patient safety, the following results are obtained.

Table 2. Statistical Test correlation between knowledge, training, and PPE compliance with the practice of patient safety among respondents in Ratu Zalecha Hospital Martapura

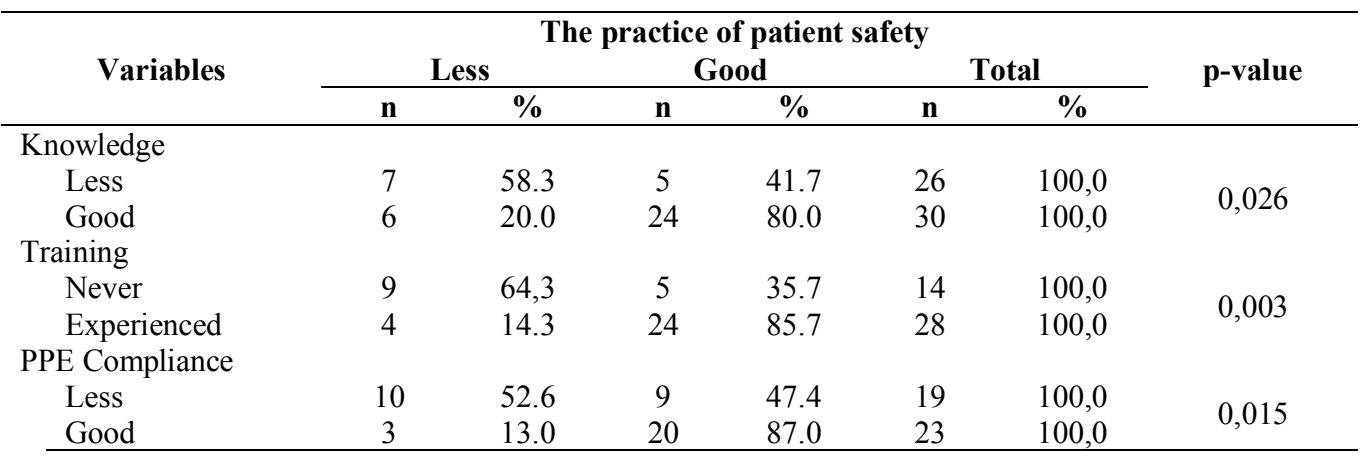

From table 2, it can be seen the results of the calculations obtained good knowledge and the practice of patient safety; there are $24(80.0 \%)$ respondents. The results of statistical tests using the chi-square test with the 95\% significance value show $p$-value $=0.026(p<0.05)$, respondents experienced and practice of patient safety there are $28(85.7 \%)$ respondents. Statistical test results using the chi-square test with 95\% confidence level in Table 2 shows pvalue $=0.003(\mathrm{p}<0.05)$, respondents with good PPE compliance, and practice of patient safety of $20(87.0 \%)$ respondents. Chi-square test results with a $95 \%$ confidence level in Table 2 show $\mathrm{p}$-value $=0.015(\mathrm{p}<0.05)$. 


\section{Discussion}

\subsection{Patient Safety}

It is known that the results of this study regarding the application of patient safety in Ratu Zalecha Martapura Regional Hospital obtained a number of 29 (69.1\%) respondents with good classification. It is known that the application of patient safety is lacked in $13(30.9 \%)$ respondents. This is based on the observation of respondents not doing handwashing with six steps of $8(61.5 \%)$ respondents, not always documenting every change in the patient's condition as many as $6(46.2 \%)$ of respondents and not reviewing the risk of falling every turn shift of $3(23.1 \%)$ respondents.

\subsection{Characteristics of respondents}

From the table in Table 1, it can be seen the result of this study regarding the knowledge of respondents in Ratu Zalecha Regional Hospital obtained a number of 30 (71.4\%) respondents with good classification. The respondents who lacked knowledge answered 10 questions incorrectly. The questions are the question of drugs with concentrated concentrations answered incorrectly by $9(75 \%)$ respondents, the question of identifying patient safety answered incorrectly by $8(66.7 \%)$ respondents, the question of the contents of the patient's bracelet answered incorrectly by $8(66.7 \%)$ respondent, questions of patient assessment with possible risk of falling answered incorrectly by $5(41.6 \%)$ respondents. Undesirable incident definition questions answered incorrectly by $4(33.3 \%)$ respondents, the question of the safety of administering drugs to patients answered incorrectly by $4(33,3 \%)$ respondents, questions about how the allergen patient's wristband answered incorrectly by 4 $(33.3 \%)$ respondents, questions limiting the number of patients and family visitors answered incorrectly by $4(33.3 \%)$ respondents, the question of handwashing only done when before and after touching the patient answered wrongly by $4(33.3 \%)$ respondents, the question of the patient safety communication process answered incorrectly by $2(16.6 \%)$ respondents, and the question of the definition of patient safety answered incorrectly by $1(8,3 \%)$ respondents.

Table 1 presented the results of this study regarding the training of respondents on the practice of patient safety in Ratu Zalecha Hospital Martapura obtained a number of 28 (66.7\%) respondents with good classification. It is known that out of 42 respondents who have never attended training in the last 1 year period, $14(33.3 \%)$ respondents divided in the operating room by $5(35.7 \%)$ respondents, in the ICU room by $5(35.7 \%)$ respondents, and nerve room as many as $4(28.6 \%)$ respondents. While the 42 respondents who experienced training in a period of time one year past that $28(66.7 \%)$ of training never followed by respondents, nursing committee $22(78.6 \%)$ of respondents and intensive nursing training base $6(21.4 \%)$ respondent.

Table 1 shows the result of this study regarding the PPE compliance among nurses to the practice of patient safety in Ratu Zalecha Hospital Martapura. There are $23(54.8 \%)$ respondents with good classification. It has a compliance of less total 19 (45.2\%) respondents. This is because respondents answered no to the question of not evaluating PPE compliance as many as 13 (68.4) respondents, not using complete PPE as many as $7(36.8 \%)$ respondents, and using PPE according to procedures as many as $5(26.3 \%)$ respondents. 


\subsection{Knowledge and the practice of patient safety}

Table 2 describes the results of the calculations obtained good knowledge and the practice of patient safety $24(80.0 \%)$ respondents. The results of statistical tests using the chi-square test with the $95 \%$ significance value shows $p$-value $=0.026(p<0.05)$.

Geller stated that knowledge is included in human factors that will influence one's health practices [8]. It is known that respondents who have applied patient safety have more good knowledge $(80.0 \%)$. While respondents who applied poor patient safety had poor knowledge (58.3\%) compared to respondents who had good knowledge $(41.7 \%)$. In the field, the respondents' knowledge was not good because the respondents lacked information related to the application of patient safety and the absence of regular audits.

\subsection{Training and the practice of patient safety}

Table 2 presented that respondents having attended training and practice of patient safety $28(85.7 \%)$ respondents. Statistical test results using the chi-square test with $95 \%$ confidence level in Table 2 shows $\mathrm{p}$-value $=0.003(\mathrm{p}<0.05)$. It is known that the respondents who applied better safety had participated in training $(85.7 \%)$ compared to respondents who had never attended the training (14.3\%) on the application of patient safety. While respondents who had poor patient safety had never attended the training $(64.3 \%)$ compared to respondents who had attended the training $(35.7 \%)$ on the application of patient safety. In the state courts of respondents who have been trained to behave safely every action of patients. The service differences have seen any room for training for the room ICU will be experienced for a situation that is not unexpected rather than space - patient hospitalization more. The results of this study are in line with Geller's safety culture theory, which states that training is included as an external factor in humans that will affect one's health practices [8].

Based on Manorek's research, et al. (2017) shows nurses' training on patient safety is related to the application of patient safety in the inpatient room of the Dr. Sam Ratulangi Tondano general hospital ( $\mathrm{p}$-value $=0,000$ ) [5]. The results of research from Fitri (2010) show that nurses' skills affect patient safety. Therefore training for nurses is important to be scheduled regularly [9].

\subsection{PPE Compliance and the practice of patient safety}

From table 2 it can be seen that respondents with good PPE compliance and practice of patient safety of $20(87.0 \%)$ respondents. Chi-square test results with a $95 \%$ confidence level in table 2 shows $p$-value $=0.015(p<0.05)$. This value indicates PPE compliance related to the application of patient safety. It is known that the respondents who apply good PPE compliance $(87.0 \%)$ towards the application of patient safety. While the respondents who have a safety application of patients who are less well over many have compliance PPE less (52.6\%) compared to respondents who have a good PPE compliance (47.4\%) against the application of patient safety. At the field level for respondents with less due to the compliance of PPE provision of PPE in the room ICU and inpatient hospitalization surgery. It often wears PPE, and PPE should have a reserved bit for the provision of PPE in the compulsory to have a spare suit the average usage amount of PPE use. 


\section{Conclusion}

From this result, it can be concluded that knowledge can affect the practice of patient safety among nurses at Ratu Zalecha Hospital Martapura. The training can also trigger the practice of patient safety among nurses at Ratu Zalecha Hospital Martapura. The existence of compliance on PPE can be part of the application of patient safety. It is recommended that hospitals can increase nurses' knowledge with OSH promotion, improve training, and improve PPE compliance with rewards.

\section{References}

[1] World Health Organization. Patient safety research. World Health Organization, Geneva, 2011.

[2] Bawelle SC, Sinolungan JSV, Hamel RS. Hubungan pengetahuan dan sikap perawat dengan pelaksanaan keselamatan pasien (patient safety) di ruang rawat inap RSUD Liun Kendage Tahuna. E-journal Keperawatan (e-Kep) 2013; 1(1): 1-7.

[3] Profil Rumah Sakit dan Data infeksi rumah sakit di RSUD Ratu Zalecha Martapura 2016-2017.

[4] Manorek H, Rattu AJM, Abeng TDE. Factors that relate to the implementation of targeted safety of patients in the nurse in the room inpatient hospitalization Home Hospital General Regional Dr Sam Ratulangi Tondano. Journ al of Public Health, 2017; 04 (02): 65-78.

[5] Arfianto. Compliance nurses in implementing targeted safety of patients at pegurangan risk of infection with the use of Personal Protective Equipment in RS Roemani Muhammadiyah Semarang. Thesis. Semarang: Diponegoro University Semarang, 2017.

[6] Sualang RMN, Kandou GD, Tilaar CR. Analysis of the characteristics and attitudes of clinical practitioners towards patient safety behavior at the Emergency Hospital Level III Robert Wolter Mongisidi Teling Manado. JIKMU, 2014; 4 (3): 468-480.

[7] Geller ES. The pshchilogy of safety handbook. USA: Lewis Publisher, 2001.

[8] Fitri A. The influence of knowledge, attitudes and skills on patient safety in H. Sahudin Kutance General Hospital. Thesis: University of North Sumatra, 2010. 